\title{
INVITRO REGENERATION OF A THREATENED MEDICINAL PLANT PHYLLODIUM PULCHELLUM L. DESV.
}

\section{GOPAL VELMURUGAN \& SUBRAMANIAM PARVATHI ANAND}

$P G \&$ Research Department of Botany, National College (Autonomous), Tiruchirappalli, Tamil Nadu, India

An efficient in vitro regeneration protocol was developed Phyllodium pulchellum (L.) Desv. A threatened medicinal plant. The plants were regeneration from shoot tip and nodal explants. The highest number of shoots per explant was obtained on the medium supplemented with $1.5 \mathrm{mg} / \mathrm{l}$ BAP + IAA $0.5 \mathrm{mg} / \mathrm{l}$ from shoot tip explants

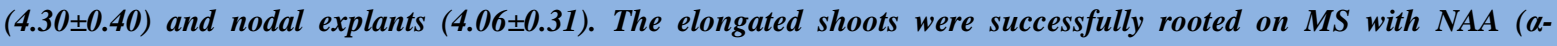
naphthalene acetic acid) or IBA; $0.75 \mathrm{mg} / \mathrm{l}$ of NAA provided better response for rhizogenesis among them. For regenerated shoots rooting, MS medium supplemented with $0.75 \mathrm{mg} / \mathrm{NAA}$ ( $\alpha$ - naphthalene acetic acid) was most effective with maximum number $(4.50 \pm 0.36$ roots per plantlet) and length $(2.76 \pm 0.15 \mathrm{~cm}$ per root) of roots respectively. Regenerated plantlets were successfully transferred into pots with soil and over $90 \%$ of them grew into healthy mature plants. This is the first report of direct organogenesis in P. Pulchellum with significantly high plantlet regeneration frequency.
\end{abstract}

KEYWORDS: Phyllodium Pulchellum, Threatened, Shoot Tip and Nodal, Plant Growth Regulator \& Regeneration

Received: Apr 03, 2017; Accepted: May 02, 2017; Published: Aug 11, 2017; Paper Id.: IJBRAUG20178

\section{INTRODUCTION}

Phyllodium pulchellum (L.) Desv. (Desmodium pulchellum (L.) Benth.) is commonly known as Tamil Vellalothi. It is a Subshrub 1(3) m; branchlets downy- pubescent to tomentose. Leaves 3-foliolate, to $15 \mathrm{~m}$; leaflets ovate or elliptic-oblong, laterals less than half as long as the terminal, in equilateral, thin-coriaceous, appressedpubescent above, tomentose below, base subacute, margin wavy, apex obtuse-acute; Racemes to $20 \mathrm{~cm}$; Stamens monadelphous; vexillary one free above middle. Overy $2 \mathrm{~mm}$, pubescent; seeds ellipsoid or orbicular, $2 \mathrm{~mm}$. Traditionally, decoction of dried leaves of Desmodium pulchellum is used in cold fever, malaria, enlargement of liver and spleen, rheumatism bone pains and swelling due to contusion or sprain. Decoction of charred roots used to reduce excessive menstrual flow. Leaves are also applied to ulcers and skin sores in hemorrhages. The whole plant is used in Chinese medicine to treat rheumatic fever, infant convulsions, toothache, and also to dissolve internal blood clots, and to aid digestion. The international union for conservation of natural and national resource has a long time ago listed Phyllodium pulchellum (L.) Desv., as a threatened species (Lopez, 2012). Some attempts were made recently for relative's species for invitro regeneration and conservation of plants (Thandar and Tun, 2015). The plant has been shown to ethanolic extract of barks may contribute to the reduction of blood glucose levels and can be useful in the management of diabetes (Noor et al., 2013). The methanolic extract of the leaves of Desmodium pulchellum, were a biological active ingredient that are active for anti-diarrheal actions (Rahman et al., 2013). The ethanolic extract of D. gangeticum can be used as a source of natural antioxidants with could serve as free radical inhibitors, scavengers or primary antioxidants (Venkatachalam and Muthukrishnan, 2012). 
However, protocol for in vitro conservation of $P$. pulchellum has not yet been established and as such the present work was undertaken to study effects of culture media composition and temperature/light conditions on in vitro propagation and slow-growth conservation.

\section{MATERIALS AND METHODS}

\section{Collection of Plant Materials}

Shoot tip and nodal part of Phyllodium pulchellum were collected from the Jambhuthu hamlet is situated at Boda hill of Namakkal District, Tamil Nadu, India and identified in Botanical survey of India, Southern regional centre under the Voucher specimen number: BSI/SRC/5/23/2012-13/Tech-1795 \& Serial No. 2.

\section{Explant Source and Sterilization}

The shoot tip and node of $P$. pulchellum were used as expalnts. These explants were washed first under running tap water for 30 minutes, then treated with $0.1 \%(\mathrm{~V} / \mathrm{V})$ aqueous solution of Tween-20 (Hi-media, Mumbai) for 15 min, followed by 5 to 6 washes with distilled water thoroughly. Explants were surface sterilized with bavistin 5\% for 5 minutes to remove the fungal contamination. Then they were rinsed in autoclaved sterile distilled water twice or thrice and were then taken to the laminar air flow chamber where they were surface sterilized with $0.1 \% \mathrm{HgCl}_{2}$ for 3-5 minutes. They were again washed twice or thrice using sterile distilled water. After repeated rinsing (five times) with distilled water, the explants were ready to inoculate on the culture media. The surface-sterilized explants were aseptically cut into 1-2 cm segments and were carefully inoculated onto the MS culture media (Murashige and Skoog, 1962).

\section{Culture Media and Culture Conditions}

The culture media consisted of MS basal constituents, supplemented with different concentration BAP, Kn and IAA. The media were supplemented with $3 \%$ sucrose and $0.8 \%$ agar was used as the gelling agent. The $\mathrm{pH}$ was adjusted with a pH meter at 5.7 adjustment was done with $0.1 \mathrm{~N} \mathrm{HCI}$ and $0.1 \mathrm{~N} \mathrm{NaOH}$ and autoclaved at $121^{\circ} \mathrm{C}, 15 \mathrm{lb}$ pressure for $45 \mathrm{~min}$. The cultures were maintained at $25 \pm 2^{\circ} \mathrm{C}, 16 / 8 \mathrm{hr}$ (light/dark) photoperiod with a light intensity of 1500 lux at relative humidity $(\mathrm{RH})$ of $60-70 \%$.

\section{Statistical Analysis}

Total number of explants taken for observation 35 (each treatment consists of at least 7 explants and the experiments were repeated three times). Data were statistically analyzed, using SPSS Statistical Software package (Ver. 16.0). The mean comparisons were carried out by DMRT at a probability level of $5 \%(\mathrm{p}<0.05)$.

\section{RESULTS}

\section{Direct Regeneration}

For direct regeneration of Phyllodium pulchellum shoot tip and node explants were used. Various plant growth regulators were used along with MS media, from that, BAP and IAA only give a high amount of response in multiple shoot induction, NAA only induced a high range of root formation.

\section{Shoot Tip Explants}

Studies were carried out to produce plantlets form shoot tip explants through direct organogenesis without intervention of callus. The results obtained are given in Table 1. BAP was used in concentration ranging from $(0.5,1.0$, 
1.5, 2.0 and $2.5 \mathrm{mg} / \mathrm{l})$, with IAA concentration $(0.5 \mathrm{mg} / \mathrm{l})$ and $\mathrm{KN}$ concentration ranging from $(0.5,1.0,1.5,2.0$ and 2.5 $\mathrm{mg} / \mathrm{l})$, with IAA concentration $(0.5 \mathrm{mg} / \mathrm{l})$. Maximum response and maximum number of shoots per explants were observed in $1.5 \mathrm{mg} / \mathrm{l}$ of BAP combination with $0.5 \mathrm{mg} / \mathrm{l}$ of IAA $(4.30 \pm 0.40)$ was relatively minimum effective in which, number of shoot in BAP of $2.5 \mathrm{mg} / \mathrm{l}(0.93 \pm 0.25)$. The frequency of culture response was 62.85 and the mean shoots produced also high in $1.5 \mathrm{mg} / \mathrm{l}$ of BAP and $0.5 \mathrm{mg} / \mathrm{l}$ of IAA combination (Table 1 and Figure 1) and the various stages in the production of plantlets by direct organogenesis.

\section{Nodal Explants}

Direct organogenesis was also carried with nodal explants of $P$. pulchellum. The observations are given in Tables 2 and Figure 2. BAP, KN and IAA were used for direct organogenesis. The concentration ranging from BAP (0.5-2.5 $\mathrm{mg} / \mathrm{l}), \mathrm{KN}(0.5-2.5 \mathrm{mg} / \mathrm{l})$ along with IAA (0.5 mg/l). Maximum response and maximum number of shoots per explants were observed in $1.5 \mathrm{mg} / \mathrm{l}$ of BAP combination with $0.5 \mathrm{mg} / \mathrm{l}$ of IAA $(4.06 \pm 0.31)$ was relatively minimum effective in which, number of shoot in $\mathrm{KN}$ of $2.5 \mathrm{mg} / \mathrm{l}(0.96 \pm 0.21)$. More or less the pattern of response was similar to the shoot tip explants. However the frequency of culture response was 77.14 and the mean shoots produced also high in $1.5 \mathrm{mg} / \mathrm{l}$ of BAP and $0.5 \mathrm{mg} / \mathrm{l}$ of IAA combination. Comparison of shoot tip explants and nodal explants reveals that the nodal explants are relatively superior both in terms of percentage of response and number of shoots is produced from the explants.

\section{ROOT INDUCTION FROM DIRECT REGENERATION}

Auxins played multifarious role in rhizogenesis, which included division of meristematic cells, their elongation and differentiation into root primordial. The number of roots produced per shoot, root length and thickness varied with the concentration of auxin used in the medium. Root induction was carried out in well elongated shoots developed from nodal explants in vitro regeneration and culturing them on MS with $0.25-1.25 \mathrm{mg} / \mathrm{l}$ of NAA and IBA. In the present study, NAA $(0.75 \mathrm{mg} / \mathrm{l})$ was found to e most effective for rooting. Maximum number of root $(4.50 \pm 0.36)$ were produced in 0.75 $\mathrm{mg} / \mathrm{l}$ of NAA and mean root length was found to be $2.76 \pm 0.15 \mathrm{~cm}$. Maximum number of roots (3.53 \pm 0.35$)$ was produced in $1.0 \mathrm{mg} / \mathrm{l}$ of IBA and mean root length was $2.63 \pm 0.15 \mathrm{~cm}$. best results of rooting were observed on the MS media supplemented with $0.75 \mathrm{mg} / \mathrm{l}$ of NAA with percentage of root induction in $66.33 \pm 3.78$ (Table 3 ).

\section{DISCUSSIONS}

Earlier reports indicate that the superiority of BAP over other cytokines in shoot induction of Dysolobium pilosum shoot tip explants (Kalva et al., 2015) and Cassia angustifolia regeneration via direct organogenesis is still BAP, KN and IAA (Iram et al., 2015). Similar observation was made in Andrographis paniculata (Purkayastha et al., 2008) and the efficiency of BA in multiple shoot induction in several aromatic and medicinal plants such as Ocimum basilicum (Sahoo et al., 1997), Withania somnifera (Sen and Sharma, 1991) and Hippophae rehnoides (Purohit et al., 2009). This was in consistent with other studies where BAP and IAA promoted the proliferation and multiplication of the shoots in number of plants (Randive, 2013; Remya et al., 2013; Skala et al., 2014).

Shoot multiplication of nodal segments of Phyllodium pulchellum was observed in present study, shoots were developed in MS medium with BAP and IAA. The results were obtained resembling to the shoot tip explants. Highest mean shoots was absorbed on $1.5 \mathrm{mg} / \mathrm{l}$ of BAP combination with $0.5 \mathrm{mg} / \mathrm{l}$ of IAA. Similar results were reported in Pterocarpus marsupium Roxb. axillary shoot proliferation on Murashige and Skoog's (MS) basal medium fortified with BAP (6-benzylaminopurine) and kinetin ( $\mathrm{Kn})$ singly or in combinations with auxins at different concentrations (Jaiswal et 
al., 2015). The role of BAP in multiple shoot production through direct organogenesis and the combination of BAP and $\mathrm{KN}$ found to be effective in Sarcostemma brevistigma previously reported by Thomas and Shankar (2009). In vitro organogenesis was achieved through direct organogenesis on MS containing of BAP at $0.25 \mathrm{mg} \mathrm{1-1}$ and NAA at $0.05 \mathrm{mg} 1$ 1 has been effective on shoot regeneration of Lathyrus chrysanthus Boiss. (Telci, 2012). Same results were reported that the genus Desmodium gangeticum (Vishwakarma et al., 2009) Effectiveness of BAP in shoot regeneration from cotyledonary nodes has been reported in several other species of leguminaceae e.g. Dalbergia tatifotia Roxb. (Pradhan et al., 1998), Arachis hypogea L. (Venkatachalam et al., 1999, Vigna mungo (L.) Hepper (Ignacimuthu et al., 1997) and Acacia nitotica subsp. indica Brenan (Dewan et al., 1992). This result is contrasting with reports on leguminous species Dalbergia sissoo Roxb. and Macrotyloma uniflorum (Arya et al., 2013; Bisht et al., 2013) where BAP gave maximum shoot proliferation. The protocol employed in the present study for in vitro shoot induction of Phyllodium pulchellum, an important plant species from Boda malai, Tamil Nadu can be useful for conservation of the endemic plants.

\section{CONCLUSIONS}

This is the first report describing a protocol for organogenesis of Phyllodium pulchellum. It is concluded that direct in vitro protocol was developed for $P$. pulchellum which could be able to produce a large number of plant lets. The highest degree of shoot induction was found on MS basal medium with BAP + IAA medium combination in the respective explants were found to be best. The organogenesis and plant regeneration system developed in this study could be utilized in future for secondary metabolites production experiments.

\section{ACKNOWLEDGEMENT}

The Author is thankful to Department of Botany, National College, and Tiruchirappalli for providing basic infrastructure facilities to carry out the research work. Financial support from UGC, Grant no. F. 41-440/2012(SR), New Delhi is gratefully acknowledged.

\section{REFERENCES}

1. Arya, I. D., Nautiyal, S., and Arya, S. (2013). Tissue culture studies on clonal variations in micropropagation of Dalbergia sissoo. International Journal of Biotechnology Research, 1(4), 58-70.

2. Bisht, V., Singh, M., Shandilya, D., Mehta, J., and Rathore, S. (2013). Effect of Plant Growth Regulators on Proliferation of Multiple Shoots and Callus Induction in Horse gram (Macrotyloma uniflorum (Lam.) Verdc.). International Journal of Rec. Biotechnology, 1(1), 1-8.

3. Dewan, A., Nanda, K., and Gupta, S. C. (1992). In vitro micropropagation of Acacia nilotica subsp. indica Brenan via cotyledonary nodes. Plant Cell Reports, 12(1), 18-21.

4. Ignacimuthu, S., Franklin, G., and Melchias, G. (1997). Multiple shoot formation and in vitro fruiting from cotyledonary nodes of Vigna mango (L.) Hepper. Current science, 73(9), 733-735.

5. Iram, S., Najat A.W. B., Kahkashan P., and Iffat, S. (2015). Influence of Plant Growth Regulators on in vitro Shoot Multiplication and Plantlet Formation in Cassia angustifolia Vahl, Braz. arch. biol. technol. 58(5), 686-691.

6. Jaiswal, S., Choudhary, M., Arya, S., and Kant, T. (2015). Micropropagation of Adult Tree of Pterocarpus Marsupium Roxb. using Nodal explants. Journal of Plant Development, 22. 21-30.

7. Kalva Bharath Kumar., Ellendula Raghu., Sateesh Suthari., Ajmeera Ragan., Vatsavaya S. Raju., and Abbagani Sadanandam. (2015). In vitro Multiple Shoot Induction from the Nodal and Shoot Tip Explants of Dysolobium pilosum (Fabaceae). 
International Journal of Current Research in Biosciences and Plant Biology, 2(9): 115-123.

8. Lopez Poveda, L. (2012). Phyllodium pulchellum. The IUCN Red List of Threatened Species 2012: e.T19891445A20128016.

9. Noor, S., Rahman, S. M., Ahmed, Z., Das, A., and Hossain, M. (2013). Evaluation of anti-inflammatory and antidiabetic activity of ethanolic extracts of Desmodium pulchellum Benth.(Fabaceae) barks on albino wistar rats. Journal of Applied Pharmaceutical Science Vol. 3 (07), pp. 048-051,

10. Pradhan, C., Pattnaik, S., and Chand, P. K. (1998). Rapid in vitro propagation of East Indian Rosewood (Dalbergia latifolia Roxb.) through high frequency shoots proliferation from cotyledonary nodes. Journal of Plant Biochemistry and Biotechnology, 7(1), 61-64.

11. Purkayastha, J., Sugla, T., Paul, A., Solleti, S., and Sahoo, L. (2008). Rapid in vitro multiplication and plant regeneration from nodal explants of Andrographis paniculata: a valuable medicinal plant. In vitro Cellular and Developmental Biology-Plant, 44(5), 442-447.

12. Purohit, V. K., Phondani, P. C., Maikhuri, R. K., Bag, N., Prasad, P., Nautiyal, A. R., and Palni, L. M. S. (2009). In vitro propagation of Hippophae rhamnoides L. from hypocotyle explants. National Academy Science Letters, 32(5/6), 163-168.

13. Rahman, M. K., Barua, S., Islam, M. F., Islam, M. R., Sayeed, M. A., Parvin, M. S., and Islam, M. E. (2013). Studies on the anti-diarrheal properties of leaf extract of Desmodium puchellum. Asian Pacific journal of tropical biomedicine, 3(8), 639643.

14. Randive, S. D. (2013). In vitro micropropagation of Enicostema axillare. Adv Appl Sci Res, 4, 321-324.

15. Remya, M., Bai, V. N., and Mutharaian, V. N. (2013). In vitro regeneration of Aristolochia tagala and production of artificial seeds. Biologia Plantarum, 57(2), 210-218.

16. Sahoo, Y., Pattnaik, S. K., and Chand, P. K. (1997). In vitro clonal propagation of an aromatic medicinal herb Ocimum basilicum L. (sweet basil) by axillary shoot proliferation. In vitro Cellular and Developmental Biology-Plant, 33(4), 293-296.

17. Skala, E., Mielicki, W., and Wysokinska, H. (2014). Tanshinones in culture of Salvia przewalskii maxim in vitro, Acta Biologica Cracoviensia s. Botanica, 56(1), 104-110.

18. Telci Kahramanogullari, C. (2012) Studies on in vitro shoot regeneration in Lathyrus chrysanthus Boiss. plant. Master of Science Thesis. Ankara University, Graduate School of Natural and Applied Sciences, Department of Field Crops, Ankara, Turkey.

19. Thandar, S., and Tun, M. O. (2015). In vitro micropropagation of Desmodium triquetrum DC., Myanmar medicinal plant. International Journal of Technical Research and Applications, 3(6), 133-138.

20. Thomas, T. D., and Shankar, S. (2009). Multiple shoot induction and callus regeneration in Sarcostemma brevistigma Wight and Arnott, a rare medicinal plant. Plant Biotechnology Reports, 3(1), 67-74.

21. Venkatachalam, P., Geetha, N., Sankara Rao, K., Jayabalan, N., and Saravanababu, S. (1999). BAP-regulated direct shoot organogenesis from cultured seedling explants of groundnut (Arachis hypogaea L.). Indian journal of experimental biology, 37, $807-812$.

22. Venkatachalam, U., and Muthukrishnan, S. (2012). Free radical scavenging activity of ethanolic extract of Desmodium gangeticum. Journal of Acute medicine, 2(2), 36-42.

23. Vishwakarma, U. R., Gurav, A. M., and Sharma, P. C. (2009). In vitro propagation of Desmodium gangeticum (L.) DC. from cotyledonary nodal explants. Pharmacognosy Magazine, 5(18), 145-150. 


\section{APPENDICES}

Table 1: Influence of Different Concentration of Either Cytokinin (BAP and KN) Alone or in Combination with Auxin (IAA) on Direct Shoot Regeneration From Shoot Tip Explants of Phyllodium Pulchellum

\begin{tabular}{|c|c|c|c|c|c|}
\hline \multicolumn{2}{|c|}{$\begin{array}{l}\text { Hormone Concentration } \\
\mathrm{mg} / \mathrm{l}(\mu \mathrm{g})\end{array}$} & $\begin{array}{c}\text { No of } \\
\text { Explants } \\
\text { Cultured }\end{array}$ & $\begin{array}{c}\text { No. of } \\
\text { Explants } \\
\text { Responded }\end{array}$ & $\begin{array}{l}\text { Frequency } \\
\text { of Culture } \\
\text { Response }\end{array}$ & $\begin{array}{c}\text { No. of } \\
\text { Shoot/Explants } \\
\text { Mean } \pm \text { SD }\end{array}$ \\
\hline \multicolumn{6}{|c|}{ BAP } \\
\hline \multicolumn{2}{|c|}{$0.5(0.11)$} & 35 & 11 & 31.42 & $1.33 \pm 0.15^{\mathrm{hij}}$ \\
\hline \multicolumn{2}{|c|}{$1.0(0.22)$} & 35 & 15 & 42.85 & $2.06 \pm 0.25^{\mathrm{de}}$ \\
\hline \multicolumn{2}{|c|}{$1.5(0.34)$} & 35 & 18 & 51.42 & $3.06 \pm 0.25^{b}$ \\
\hline \multicolumn{2}{|c|}{$2.0(0.45)$} & 35 & 12 & 34.28 & $1.80 \pm 0.20^{\mathrm{efg}}$ \\
\hline \multicolumn{2}{|c|}{$2.5(0.56)$} & 35 & 9 & 25.71 & $0.93 \pm 0.25^{\mathrm{jk}}$ \\
\hline \multicolumn{6}{|c|}{ KN } \\
\hline \multicolumn{2}{|c|}{$0.5(0.11)$} & 35 & 8 & 22.85 & $1.00 \pm 0.20^{\mathrm{jk}}$ \\
\hline \multicolumn{2}{|c|}{$1.0(0.22)$} & 35 & 10 & 28.57 & $1.73 \pm 0.20^{\text {efgh }}$ \\
\hline \multicolumn{2}{|c|}{$1.5(0.32)$} & 35 & 13 & 37.14 & $2.13 \pm 0.15^{\text {cde }}$ \\
\hline \multicolumn{2}{|c|}{$2.0(0.43)$} & 35 & 9 & 25.71 & $1.20 \pm 0.20^{\mathrm{ijk}}$ \\
\hline \multicolumn{2}{|c|}{$2.5(0.53)$} & 35 & 6 & 17.14 & $0.86 \pm 0.15^{\mathrm{k}}$ \\
\hline \multicolumn{6}{|c|}{ BAP+IAA } \\
\hline $0.5(0.11)$ & $0.5(0.08)$ & 35 & 15 & 42.85 & $2.53 \pm 0.30^{c}$ \\
\hline $1.0(0.22)$ & $0.5(0.08)$ & 35 & 18 & 51.42 & $3.33 \pm 0.20^{\mathrm{b}}$ \\
\hline $1.5(0.34)$ & $0.5(0.08)$ & 35 & 22 & 62.85 & $4.30 \pm 0.40^{\mathrm{a}}$ \\
\hline $2.0(0.45)$ & $0.5(0.08)$ & 35 & 17 & 48.57 & $3.28 \pm 0.38^{b}$ \\
\hline $2.5(0.56)$ & $0.5(0.08)$ & 35 & 12 & 34.28 & $2.47 \pm 0.33^{\mathrm{cd}}$ \\
\hline \multicolumn{6}{|c|}{ KN+IAA } \\
\hline $0.5(0.11)$ & $0.5(0.08)$ & 35 & 8 & 22.85 & $1.45 \pm 0.24^{\text {ghi }}$ \\
\hline $1.0(0.22)$ & $0.5(0.08)$ & 35 & 11 & 31.42 & $1.90 \pm 0.11^{\mathrm{ef}}$ \\
\hline $1.5(0.32)$ & $0.5(0.08)$ & 35 & 17 & 48.57 & $2.42 \pm 0.24^{\mathrm{cd}}$ \\
\hline $2.0(0.43)$ & $0.5(0.08)$ & 35 & 13 & 37.14 & $1.51 \pm 0.15^{\text {fghi }}$ \\
\hline $2.5(0.53)$ & $0.5(0.08)$ & 35 & 10 & 28.57 & $1.19 \pm 0.09^{\mathrm{ijk}}$ \\
\hline
\end{tabular}

- Total number of explants taken for observation $=35$ (each treatment consists of at least 7 explants and the experiments were repeated three times).

- Mean values followed by various letters are significantly different from each other at $\mathrm{P}<0.05$ level comparison (DMRT).

Table 2: Influence of Different Concentration of Either Cytokinin (BAP and KN) Alone or in Combination with Auxin (IAA) on Direct Shoot Regeneration From Nodal Explants of Phyllodium Pulchellum

\begin{tabular}{|c|c|c|c|c|}
\hline $\begin{array}{c}\text { Hormone Concentration } \\
\text { mg/l }(\boldsymbol{\mu g})\end{array}$ & $\begin{array}{c}\text { No of } \\
\text { Explants } \\
\text { Cultured }\end{array}$ & $\begin{array}{c}\text { No. of } \\
\text { Explants } \\
\text { Responded }\end{array}$ & $\begin{array}{c}\text { Frequency } \\
\text { of Culture } \\
\text { Response }\end{array}$ & $\begin{array}{c}\text { No. of } \\
\text { Shoot/Explants } \\
\text { Mean } \mathbf{\text { SDD }}\end{array}$ \\
\hline \multicolumn{5}{|c|}{ BAP } \\
\hline $0.5(0.11)$ & 35 & 13 & 37.14 & $1.45 \pm 0.07^{\mathrm{gh}}$ \\
\hline $1.0(0.22)$ & 35 & 17 & 48.57 & $2.32 \pm 0.47^{\mathrm{d}}$ \\
\hline $1.5(0.34)$ & 35 & 20 & 57.14 & $3.21 \pm 0.32^{\mathrm{b}}$ \\
\hline $2.0(0.45)$ & 35 & 15 & 42.85 & $1.64 \pm 0.08^{\mathrm{fg}}$ \\
\hline $2.5(0.56)$ & 35 & 11 & 31.42 & $1.39 \pm 0.13^{\mathrm{gh}}$ \\
\hline $\mathbf{K N}$ & 35 & 10 & 28.57 & $1.09 \pm 0.21^{\mathrm{hi}}$ \\
\hline $0.5(0.11)$ & 35 & 13 & 37.14 & $1.65 \pm 0.18^{\mathrm{fg}}$ \\
\hline $1.0(0.22)$ & 35 & 15 & 42.85 & $2.00 \pm 0.92^{\mathrm{def}}$ \\
\hline $1.5(0.32)$ & \multicolumn{5}{|l}{}
\end{tabular}




\begin{tabular}{|c|c|c|c|c|c|}
\hline \multicolumn{2}{|c|}{$2.0(0.43)$} & 35 & 11 & 31.42 & $1.63 \pm 0.04^{\mathrm{fg}}$ \\
\hline \multicolumn{2}{|c|}{$2.5(0.53)$} & 35 & 9 & 25.71 & $0.96 \pm 0.21^{\mathrm{i}}$ \\
\hline \multicolumn{6}{|c|}{ BAP+IAA } \\
\hline $0.5(0.11)$ & $0.5(0.08)$ & 35 & 17 & 48.57 & $2.84 \pm 0.08^{\mathrm{c}}$ \\
\hline $1.0(0.22)$ & $0.5(0.08)$ & 35 & 23 & 65.71 & $3.25 \pm 0.10^{b}$ \\
\hline $1.5(0.34)$ & $0.5(0.08)$ & 35 & 27 & 77.14 & $4.06 \pm 0.31^{\mathrm{a}}$ \\
\hline $2.0(0.45)$ & $0.5(0.08)$ & 35 & 22 & 62.85 & $3.30 \pm 0.14^{b}$ \\
\hline $2.5(0.56)$ & $0.5(0.08)$ & 35 & 15 & 42.85 & $2.73 \pm 0.24^{\mathrm{c}}$ \\
\hline \multicolumn{6}{|c|}{ KN+IAA } \\
\hline $0.5(0.11)$ & $0.5(0.08)$ & 35 & 11 & 31.42 & $1.65 \pm 0.08^{\mathrm{fg}}$ \\
\hline $1.0(0.22)$ & $0.5(0.08)$ & 35 & 13 & 37.14 & $2.06 \pm 0.14^{\mathrm{de}}$ \\
\hline $1.5(0.32)$ & $0.5(0.08)$ & 35 & 23 & 65.71 & $2.97 \pm 0.24^{\text {bc }}$ \\
\hline $2.0(0.43)$ & $0.5(0.08)$ & 35 & 15 & 42.85 & $1.94 \pm 0.11^{\mathrm{ef}}$ \\
\hline $2.5(0.53)$ & $0.5(0.08)$ & 35 & 12 & 34.28 & $1.34 \pm 0.15^{\mathrm{gh}}$ \\
\hline
\end{tabular}

- Total number of explants taken for observation $=35$ (each treatment consists of at least 7 explants and the experiments were repeated three times).

- Mean values followed by various letters are significantly different from each other at $\mathrm{P}<0.05$ level comparison (DMRT).

Table 3: Effect of Growth Regulator on Root Induction of Phyllodium Pulchellum L. Desv

\begin{tabular}{|c|c|c|c|}
\hline $\begin{array}{c}\text { Growth } \\
\text { Regulators (mg/l) }\end{array}$ & $\begin{array}{c}\text { Percentage of } \\
\text { Root Inducted } \\
\text { Mean } \pm \text { SD }\end{array}$ & $\begin{array}{c}\text { No. of } \\
\text { Roots/Shoots } \\
\text { Mean } \pm \text { SD }\end{array}$ & $\begin{array}{c}\text { Root Length } \\
\text { (cm) } \\
\text { Mean } \pm \text { SD }\end{array}$ \\
\hline \multicolumn{4}{|c|}{ NAA } \\
\hline 0.25 & $35.66 \pm 1.52^{\mathrm{e}}$ & $2.36 \pm 0.11^{\mathrm{d}}$ & $0.60 \pm 0.20^{\mathrm{e}}$ \\
\hline 0.50 & $48.33 \pm 3.05^{\mathrm{c}}$ & $3.46 \pm 0.35^{\mathrm{b}}$ & $1.76 \pm 0.15^{\mathrm{bc}}$ \\
\hline 0.75 & $66.33 \pm 3.78^{\mathrm{a}}$ & $4.50 \pm 0.36^{\mathrm{a}}$ & $2.76 \pm 0.15^{\mathrm{a}}$ \\
\hline 1.0 & $40.66 \pm 2.08^{\mathrm{de}}$ & $3.23 \pm 0.32^{\mathrm{b}}$ & $1.43 \pm 0.20^{\mathrm{cd}}$ \\
\hline 1.25 & $29.00 \pm 2.00^{\mathrm{f}}$ & $2.30 \pm 0.26^{\mathrm{d}}$ & $0.56 \pm 0.25^{\mathrm{e}}$ \\
\hline \multicolumn{4}{|c|}{ IBA } \\
\hline 0.25 & $26.33 \pm 2.51^{\mathrm{f}}$ & $1.73 \pm 0.20^{\mathrm{e}}$ & $0.33 \pm 0.15^{\mathrm{e}}$ \\
\hline 0.50 & $35.66 \pm 3.51^{\mathrm{e}}$ & $2.30 \pm 0.17^{\mathrm{d}}$ & $1.13 \pm 0.20^{\mathrm{d}}$ \\
\hline 0.75 & $43.00 \pm 2.64^{\mathrm{d}}$ & $2.93 \pm 0.15^{\mathrm{c}}$ & $2.03 \pm 0.20^{\mathrm{b}}$ \\
\hline 1.0 & $55.66 \pm 3.51^{\mathrm{b}}$ & $3.53 \pm 0.35^{\mathrm{b}}$ & $2.63 \pm 0.15^{\mathrm{a}}$ \\
\hline 1.25 & $25.00 \pm 3.60^{\mathrm{f}}$ & $2.23 \pm 0.20^{\mathrm{d}}$ & $1.33 \pm 0.41^{\mathrm{d}}$ \\
\hline
\end{tabular}

Mean values followed by various letters are significantly different from each other at

$\mathrm{P}<0.05$ level comparison (DMRT). 
Direct Organogenesis from Shoot tip Explant of Phyllodium pulchellum
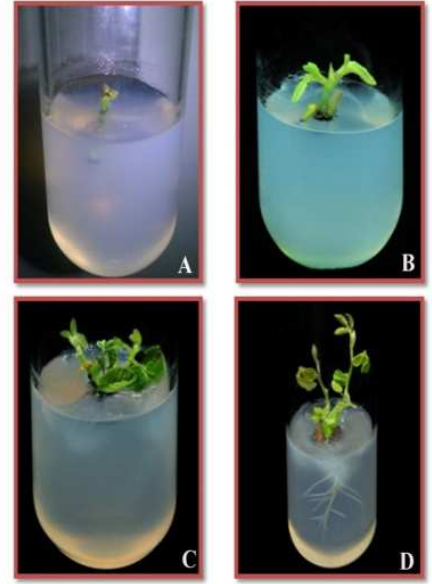

A) \& B) Shoot initiation from nodal explants on MS medium $+1.5 \mathrm{mg} /$ of BAP combination with $0.5 \mathrm{mg} / \mathrm{o}$ of IAA.

C) Shoot induction on $M S+B A P 1.5 \mathrm{mg} / \mathrm{l}+I A A 0.5 \mathrm{mg} /$.

D) Shoot elongation a rooting on MS Medium with $0.75 \mathrm{mg} / \mathrm{lof} N A A$.

Figure 1
Direct Organogenesis from Nodal Explant of Phyllodium pulchellum
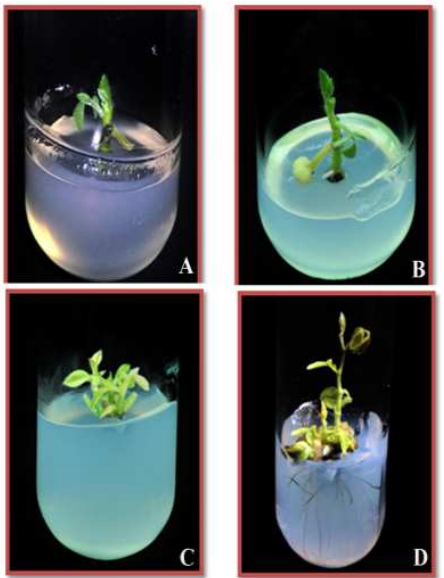

1) \& B) Shoot initiation from shoot tip explants on MS medium $+1.5 \mathrm{mg} /$ of $B A P$ combination with $0.5 \mathrm{mg} /$ of IAA.

Shoot induction on MS + BAP $1.5 \mathrm{mg} / \mathrm{l}+\mathrm{IAA} 0.5 \mathrm{mg} / \mathrm{l}$

D) Shoot elongation a rooting on MS Medium with $0.75 \mathrm{mg} / \mathrm{of} \mathrm{NAA}$.

Figure 2 